\title{
Effects of Human Hair and Nail Proteins and Their Films on Rat Mast Cells
}

\author{
Toshihiro Fujii, ${ }^{1, *}$ Shinya Murai, ${ }^{1}$ Kousaku Ohkawa, ${ }^{2}$ and Toshihiro Hirai ${ }^{3}$ \\ ${ }^{1}$ Department of Kansei Engineering, ${ }^{2}$ Institute of High Polymer Research, and \\ ${ }^{3}$ Department of Materials Chemistry, Faculty of Textile Science and Technology, \\ Shinshu University, Tokida 3-15-1, Ueda 386-8567, Japan \\ * To whom correspondence should be addressed. \\ E-mail: fujiit1@shinshu-u.ac.jp \\ Tel: +81-268-215518 Fax: +81-268-215511
}


Summary: Human hair and nail are valuable materials for producing individual corresponding biocompatible materials. A rapid and convenient protein extraction method (Shindai method) and novel procedures for preparing their protein films from their extracts have been developed using human hair and nail. The effects of the human hair and nail proteins and their films on histamine release from rat peritoneal mast cells were investigated. Both protein solutions and their films, mainly consisting of keratins and matrix proteins, did not induce histamine release from the mast cells. Scanning electron microscopy (SEM) also showed that the mast cells were only slightly affected by adding the human hair and nail proteins or by incubating on their protein films. The IgE-dependent histamine release was inhibited by the hair and nail proteins and their films. Incubation of the mast cells with the hair and nail proteins prior to the addition of the IgE serum resulted in a high inhibition $(50 \%)$ of the histamine release, while the inhibition was approximately $10 \%$ when the protein solutions were mixed with the mast cells after incubation with the IgE serum. These results suggest that the human hair and nail proteins and their films will be useful materials for antiallergic actions.

Keywords: human hair and nail, protein extraction, protein films, mast cell, histamine release, degranulation 


\section{Introduction}

Human hair and nail are valuable materials for producing individual corresponding biocompatible materials. Hair proteins mainly consist of microfibrial $\alpha$-keratins with molecular masses of $40-65 \mathrm{kDa}$ and matrix proteins with 10-20 kDa based on sodium dodecyl sulfate-polyacrylamide gel electrophoresis (SDS-PAGE). A rapid and convenient protein extraction method (Shindai method) was developed for quantifying the human hair and nail components. ${ }^{[1]}$ The amount of protein extracted by the Shindai method was 2.5-3.5 times more than those obtained by other conventional methods. ${ }^{[1,2]}$

Novel procedures were also developed for preparing human hair protein films (Pre-cast, Post-cast, and soft Post-cast methods). ${ }^{[2-4]}$ These protein films were water-insoluble and mainly consisted of $\alpha$-keratin. Reinforcement of the human hair protein films with cotton gauze made it possible to apply them on human skin for several days. A patch test using human skin indicated that the protein films made from individual and multiple human hairs did not cause itching, drying smarting, and pain on the contact areas of arms. ${ }^{[4]}$ Yamauchi et al. reported that mouse fibroblast cells adhered, spread and grew on wool keratin-coated dishes as well as collagen- and polyvinyl alcohol-coated ones. ${ }^{[5]}$ Few problems with the cultivation of the fibroblast cells were also confirmed using wool keratin sponge scaffolds. ${ }^{[6]}$ We examined the antibody-producing activity against mouse body hair proteins, human hair proteins, and human nail proteins using BALB/c mice. The reactivity of sera against the mouse body hair proteins was less than those against the human hair and nail proteins, indicating the presence of an immunological specificity. ${ }^{[7]}$ The protein films prepared from human hair and wool were biodegraded by proteases. ${ }^{[8,9]}$ 
Mast cells are widely distributed throughout the epithelia and vascularized tissues and responsible for type I allergic disorders such as dermatitis, allergic rhinitis and fool allergies. ${ }^{[10,11]}$ Mast cells release histamine and other potent inflammatory mediators in response to various stimuli. The interaction between the IgE-directed antigen and the IgE receptors on the mast cell surfaces causes cross-linking between the IgE receptors and the release granules, the latter of which contain the performed inflammatory mediators and generate inflammatory lipids and cytokines. ${ }^{[11,12]}$ The stimulation of mast cells is also induced by proteins and peptides. ${ }^{[12,13]}$

The allergic effects of the hair protein containing $\alpha$-keratins have not yet been studied. As model experiments, we examined the effects of the human hair and nail proteins and their films on rat peritoneal mast cells.

\section{Materials and Methods}

\section{Preparation of Mast Cells}

Peritoneal mast cells were obtained from the abdominal cavities of the male rat (Wister; 300-400 g). ${ }^{[13]}$ Briefly, the rats were anesthetized with ether and injected with $20 \mathrm{~mL}$ of mast cell medium (MCM) which was comprised of 144 $\mathrm{mM} \mathrm{NaCl}, 2.7 \mathrm{mM} \mathrm{KCl}, 4.7 \mathrm{mM} \mathrm{Na}_{2} \mathrm{HPO}_{4}, 2 \mathrm{mM} \mathrm{KH}_{2} \mathrm{PO}_{4}, 5.6 \mathrm{mM}$ glucose, 10 $\mathrm{U} \cdot \mathrm{mL}^{-1}$ heparine and $1 \mathrm{mg} \cdot \mathrm{mL}^{-1}$ bovine serum albumin (BSA), $\mathrm{pH} 7$, into the peritoneal cavity, and then the abdomen was massaged for about 5 min. The peritoneal cavity was opened and the fluid was collected using a pipette. The mast cells were purified to at least $95 \%$ homogeneity by centrifugation through 
a $2 \mathrm{~mL}$ cushion of $24 \%$ metrizamide, and washed twice by centrifugation at $4{ }^{\circ} \mathrm{C}$.

The cells were re-suspended in MCM buffer at a density of approximately

$5 \times 10^{5} \mathrm{~mL}^{-1}$ and used for each experiment.

Preparation of Human Hair and Nail Protein and Their Films

Human hair and nail protein solutions were prepared according to the "Shindai method", which has been previously described by us. ${ }^{[1,2]}$ Briefly, the human hair and nail were washed with ethanol and incubated with a solution consisting of 2.6 M thiourea, $5 \mathrm{M}$ urea, 5\% 2-mercaptoethanol, and $25 \mathrm{mM}$ Tris- $\mathrm{HCl}(\mathrm{pH}$ $8.5)$ at $50{ }^{\circ} \mathrm{C}$ for $2-4$ days. After filtration, the solution was dialyzed against MCM buffer without BSA for 3-4 days at $25{ }^{\circ} \mathrm{C}$. The obtained dialysate was further centrifuged at $15,000 \times g$ for $20 \mathrm{~min}$ at $25^{\circ} \mathrm{C}$, and the supernatant was used as the protein solution.

The human hair and nail protein films were prepared by the Post-cast and soft Post-cast methods. ${ }^{[3,4]}$ The hair and nail proteins dissolved in the Shindai solution were cast in solution containing $100 \mathrm{mM}$ acetate buffer (pH 4 and 5) (Post-cast method) and $40 \mathrm{mM} \mathrm{MgCl} 2$ (soft Post-cast method). After standing for $1 \mathrm{~h}$ at room temperature, membrane-like protein films were formed and washed by rinsing with water for 36-48 $\mathrm{h}$ and then immersed (replaced) into MCM for $12-15 \mathrm{~h}$.

Sodium dodecyl sulfate-polyacrylamide gel electrophoresis (SDS-PAGE) was carried out on a $13.5 \%$ polyacrylamide gel according to the method of Laemmli. ${ }^{[14]}$ Proteins in the gel were stained with $0.1 \%$ Coomassie brilliant blue R-250, $10 \%$ acetic acid and $40 \%$ ethanol for $1-3 \mathrm{~h}$ and destained in $10 \%$ acetic acid and $40 \%$ ethanol. The protein concentrations were determined 
according to Bradford ${ }^{[15]}$ using BSA as the standard.

Assay of IgE-Independent and-Dependent Histamine Release

The suspended mast cells $\left(2 \times 10^{4}\right.$ per tube $)$ were preincubated with the hair and nail proteins or on the dishes coated with protein films for 5 min at $37{ }^{\circ} \mathrm{C}$.

After the addition of $0.1 \mathrm{mM} \mathrm{CaCl}_{2}$, the cell suspension was further incubated for $10 \mathrm{~min}$ at $37^{\circ} \mathrm{C}$. The reactions were terminated by adding $1.8 \mathrm{~mL}$ of ice-cold MCM buffer containing $1 \mathrm{mM}$ EGTA. The mast cells were stimulated by compound $48 / 80\left(0-0.4 \mu \mathrm{g} \cdot \mathrm{mL}^{-1}\right)$.

The IgE sensitized mast cells were prepared by incubation for 60 min at $37^{\circ} \mathrm{C}$ with rat IgE and phosphatidyl serine $\left(50 \mu \mathrm{g} \cdot \mathrm{mL}^{-1}\right)$ and then washed once by centrifugation. The mast cells $(0.18 \mathrm{~mL})$ were preincubated with the hair and nail proteins or on the dishes coated with the protein films for $5 \mathrm{~min}$ at $37^{\circ} \mathrm{C}$ and ovalbumin as an antigen at $50 \mu \mathrm{g} \cdot \mathrm{mL}^{-1}(0.02 \mathrm{~mL})$ was added to the sensitized cells for stimulation. Incubation was carried out for $10 \mathrm{~min}$ at $37{ }^{\circ} \mathrm{C}$, and the reactions were stopped by adding $1.8 \mathrm{~mL}$ of ice-cold MCM. After centrifugation, the histamine content of the supernatant $(1 \mathrm{~mL})$ was determined using $o$-phthalaldehyde as described by Shore et al. ${ }^{[16]}$ The total histamine was released by disrupting the cells with boiling. Histamine release from the mast cells was calculated using the following equation: [(histamine release) (spontaneous histamine release)] / (total histamine - spontaneous histamine release) $\times 100$.

Scanning Electron Microscopy (SEM) Observation Mast cells were prefixed with $2.5 \%$ glutaraldehyde and postfixed with $1 \% \mathrm{OsO}_{4}$. 
The cells were dehydrated in a graded alcohol series and critical point-dried using liquid $\mathrm{CO}_{2}$. The protein films were sputtered with gold and examined using a scanning electron microscope (Hitachi S-2380N). ${ }^{[17]}$

\section{Results and Discussion}

Effect of Hair and Nail Proteins on Mast Cells

The human hair and nail proteins were prepared by the Shindai method, and their protein components were analyzed by SDS-PAGE (Figure 1A). The hair protein sample was comprised of the type I (acidic) and type II (neutral/basic) hard $\alpha$-keratins and matrix proteins. The nail protein sample contains both the hard $\alpha$-keratins and the soft keratin, the latter of which has a molecular mass of $56 \mathrm{kDa}^{[1,2]}$

When the mast cells were incubated with the hair and nail protein samples $\left(0-5 \mathrm{mg} \cdot \mathrm{mL}^{-1}\right)$, no significant release of histamine was observed in the presence and absence of $\mathrm{Ca}^{2+}$ (Figure 1B), whereas the addition of compound $48 / 80$, a representative stimulator, triggered the histamine release in a concentration-dependent manner (Figure 1C).

\section{Morphology of Mast Cells Incubated with the Proteins}

The surface of the mast cells with diameters of $10-20 \mu \mathrm{m}$ represents a number of granules (diameters, $0.2-0.5 \mu \mathrm{m}$ ), which contain the pre-formed inflammatory mediators, such as histamine, serotonin, and substance $\mathrm{P} .{ }^{[12,13]}$ Immunological and non-immunological stimuli cause degranulation that releases 
the mediators from the granules.

Figure 2 shows SEM pictures of the mast cells. After stimulation, the appearances of the mast cell surfaces were different from those of the non-stimulated cells whose surfaces were covered with lamellar architectures, which correspond to the granule structures containing the inflammatory mediators. In the presence of compound $48 / 80(0.2 \mu \mathrm{g} \cdot \mathrm{mL})$, the granule structures were observed on the surfaces of the mast cells. The addition of the hair or nail proteins did not apparently affect the morphology of the mast cells. These results clearly suggest that the human hair and nail proteins had little or no stimulating effect on the peritoneal mast cells.

\section{Mast Cells on Hair or Nail Protein Films}

In a series of our previous studies, we have developed conventional methods to prepare stable films from the human hair and nail proteins. ${ }^{[3,4]}$ Figure 3 shows the surface of the hair protein films based on SEM observations. As previously reported, ${ }^{[3,4]}$ the surface of the protein film prepared by the Post-cast method (acetate buffer $\mathrm{pH} 4$ ) was rough and covered with a filamentous structure which contains smaller particles having diameters of $0.5-2 \mu \mathrm{m}$ (Figure 3A). The surface of the film prepared by the soft Post-cast method was smoother (Figure 3B) than that by the Post-cast method (Figure 3C). When the proteins from the hair and nail protein films were extracted again and they were then analyzed by SDS-PAGE, the enriched protein components were found as the hard keratin for the hair protein films and as the hard plus soft keratins for the nail protein films (data not shown).

The mast cells were exposed to the dishes coated with the hair and nail 
protein films and incubated for $0-90 \mathrm{~min}$ at $37^{\circ} \mathrm{C}$, then the release of histamine and the morphological changes of the mast cell surfaces were examined (Figure 4). Time-dependent continuous releases of histamine (approximately 4\%) from the mast cells were found in the hair and nail protein films as well as the control polystyrene dish (Figure 4A). These results indicate the spontaneous degranulation occurred during the incubation periods. SEM observations also revealed no significant morphological change in the mast cells, which were attached on the films after incubation for $60 \mathrm{~min}$ (Figure 4B). This result strongly suggests that the hair and nail protein films, like their protein solutions (Figures 1 and 2), had little stimulating effect on the mast cells.

\section{IgE-Dependent Histamine Release}

The release of the pre-formed inflammatory mediators is generally triggered by a cross-linking between the IgE receptors and the polyvalent allergens on the mast cell surfaces. We prepared a serum containing anti-ovalbumin IgE from a rat and constructed an experimental system for IgE-dependent exocytosis. The mast cells were preincubated with the serum and phosphatidyl serine vesicles for $60 \mathrm{~min}$ at $37^{\circ} \mathrm{C}$ in order to prepare the IgE-sensitized mast cells. When ovalbumin as an antigen was added to the IgE-sensitized mast cells, the extent of the histamine release increased with the increasing concentration of the applied ovalbumin (Figure 5A). The maximum histamine release reached approximately $20-25 \%$ of the total histamine content.

The effects of the hair and nail proteins on the IgE-dependent histamine release were subsequently examined using two procedures. First, when the mast cells were preincubated with the hair and nail proteins for $5 \mathrm{~min}$ at $37^{\circ} \mathrm{C}$ 
before incubation with the IgE serum and then stimulated by the addition of ovalbumin, the histamine release was inhibited up to approximately $50 \%$ in the presence of the hair and nail proteins above $0.5 \mathrm{mg} \cdot \mathrm{mL}^{-1}$ (Figure $5 \mathrm{~B}$ ). Next, when the hair and nail proteins were added to the mast cell solutions after incubation with the IgE serum and then stimulated by ovalbumin, approximately $10 \%$ of the histamine release was inhibited by over $0.5 \mathrm{mg} \cdot \mathrm{mL}^{-1}$ of the hair and nail proteins (Figure 5C). The extent of the inhibition was higher when the mast cells were preincubated with the hair and nail proteins prior to the addition of IgE.

We examined the effects of the hair and nail protein films on the IgE-dependent histamine release from the mast cells (Figure 6). The IgE-sensitized mast cells were preincubated for $60 \mathrm{~min}$ at $37^{\circ} \mathrm{C}$ on the dishes coated with the hair and nail protein films as shown in Figure 4. After incubation, ovalbumin was added to the dishes and further incubated for $10 \mathrm{~min}$ at $37^{\circ} \mathrm{C}$. Similar to the previous results, addition of ovalbumin stimulates the IgE-sensitized mast cell for the histamine release. The extent of the histamine release from the mast cells attached on the protein films was approximately $60 \%$ compared to that from the mast cells on the control dishes. No significant difference was found between the hair and nail protein films. These results indicated that the hair and nail proteins and their films suppressed the IgE-induced histamine release from the mast cells, and the extent of inhibition was dependent on the order of addition of the protein, IgE, and mast cells.

The antiallergic effects towards rat mast cells in vitro were analyzed as part of our continuing research of the human hair proteins and their films having biocompatibility. In this study, unlike compound $48 / 80$, the human hair and 
nail proteins and their films did not directly stimulate the mast cells. The mast cells were stimulated by proteins and peptides including protamine, salmine, clupenine, mast cell degranulating peptide, melitin, and mastparan, and substance $\mathrm{P}^{[13,18,19]}$ Most of these proteins and peptides are basic, and three or more basic amino acids are repetitively arranged in their primary structures. Hard keratins occurring in hairs and nails are classified into two subfamilies, which consist of at least 4-9 distinct type I acidic members $(40-50 \mathrm{kDa})$ and 4-6 type II neutral/basic $(55-65 \mathrm{kDa})$ members. ${ }^{[20-22]}$ Among the amino acid sequences of the keratins, the trilysyl (KKK) sequences were located in the type II keratin Hb3 (249-252), while the other repeating sequences found in the keratin do not contain the KKK or triarginyl (RRR) sequence. ${ }^{[22,23]}$ Tertiary structures of the intermediate filament proteins are generally constructed from three domains, i.e., head, rod, and tail. The KKK sequence of Hb3 was located in the rod domain, which is essential for the assembly of proteins into filaments. This indicates that the KKK sequence that localizes inside the Hb3 molecule cannot directly contact the mast cell surfaces, so that the hair and nail proteins, enriched in keratin, do not stimulate the histamine release from the mast cells.

\section{Conclusion}

In the present study, we confirmed the inhibitory effects of the human hair and nail proteins and their films on the IgE receptor-stimulated histamine release from mast cells. These findings indicate that the human hair and nail proteins and their films actually interact with IgE, because the inhibition became more remarkable when the mast cells were preincubated with the hair and nail proteins prior to the addition of $\operatorname{IgE}$ than that when the cells were preincubated 
with IgE prior to the addition of the proteins. Human hair and nail are easily collected at an individual level and the extraction by the Shindai method recovers the hair and nail proteins in a high yield. The extracted proteins are fabricated into films, ${ }^{[3-5]}$ fibers,${ }^{[24]}$ and microspheres ${ }^{[25]}$ from their aqueous solutions. Thus, these products will become some of the self-originating materials with promising biocompatibilities. The potential application of the present materials encompasses health care, cosmetic, and medical uses, such as wound dressing films or drug releasing films.

\section{Acknowledgments}

This study was supported in part by Grants-in-Aid for Science Research (B) (16350123) and CLUSTER (the second stage) from the Ministry of Education, Culture, Sports, Science and Technology of Japan. We are also indebted to the Division of Gene Research Center, Research Center for Human and Environmental Science, Shinshu University, for providing the facilities.

\section{References}

[1] A. Nakamura, M. Arimoto, K. Takeuchi, T. Fujii, Biol. Pharm. Bull. $\mathbf{2 0 0 2}, 25,569$.

[2] T. Fujii, S. Murai, Kobunshi Ronbunshu 2005, 62, 201.

[3] T. Fujii, D. Ogiwara, M. Arimoto, Biol. Pharm. Bull. 2004, 27, 89.

[4] T. Fujii, Y. Ide, Biol. Pharm. Bull. 2004, 27, 1433.

[5] K. Yamauchi, M. Maniwa, T. Mori, J. Biomater. Sci. Polym. Ed. 1998, 9, 259.

[6] A. Tachibana, Y. Furuta, H. Takeshima, T. Tanabe, K. Yamauchi, J. 
Biotech. 2002, 93, 165.

[7] Y. Ide, T. Fujii, Sen'I Gakkishi 2004, 60, 276.

[8] K. Yamauchi, A. Yamauchi, T. Kusunoki, A. Khoda, Y. Konishi, J. Biomed. Mater. Res. 1996, 31, 439.

[9] Y. Ide, T. Fujii, Kobunshi Ronbunshu 2004, 61, 153.

[10] T.Ishizaka, K. Ishizaka, Prog. Allergy 1984, 34, 188.

[11] S. M. Miescher, M. Vogel, Mol. Aspects Med. 2002, 23, 413.

[12] L. J. Walsh, Crit. Rev Oral Biol. Med. 2003, 14, 188.

[13] T. Fujii, H. Yokoyama, G.F. Li, H. Tada, Biol. Pharm. Bull. 1997, 20, 79.

[14] U.K. Laemmli, Nature 1970, 227, 680.

[15] M. M. Bradford, Anal. Biochem. 1976, 72, 248.

[16] P. A. Shore, A. Burkhalter,.V. H. Cohn Jr, J. Pharmacol. Exp. Ther. 1959, $127,182$.

[17] K. Izushi, K. Tasaka, Immunopharmacol. 1989, 18, 177.

[18] B. Jansani, G. Kreil, B.F. Mackler, D. R. Stanworth, Biochem. J. 1979, 181,623 .

[19] A. Argiolas, J. J. Pisano, J. Biol. Chem. 1990, 260, 1437.

[20] H. W. Heid, E. Werner, W. W. Franke. Differentiation 1986, 32, 101.

[21] L. Langbein, M. A. Rogers, H. Winter, S. Praetzel, U. Beckhaus, , H.-R. Rackwitz, J. Schweizer, J. Biol. Chem. 1999, 274, 19874.

[22] L. Langbein, M. A. Rogers, H. Winter, S. Praetzel, J. Schweizer, J. Biol. Chem. 2001, $276,35123$.

[23] M. A. Rogers, H. Winter, L. Langbein, C. Wolf, J. Schweizer, J. Invest. Dermatol. 2000, 114, 464. 
[24] Y. Hirao, K. Ohkawa, H. Yamamoto, T. Fujii, Macromol. Mater. Eng. 2005, 290, 165.

[25] S. Kobayashi, H. Morikawa, S. Ishii, T. Fujii, JSME Int. J. Ser. C 2005, $48,494$. 


\section{Figures}
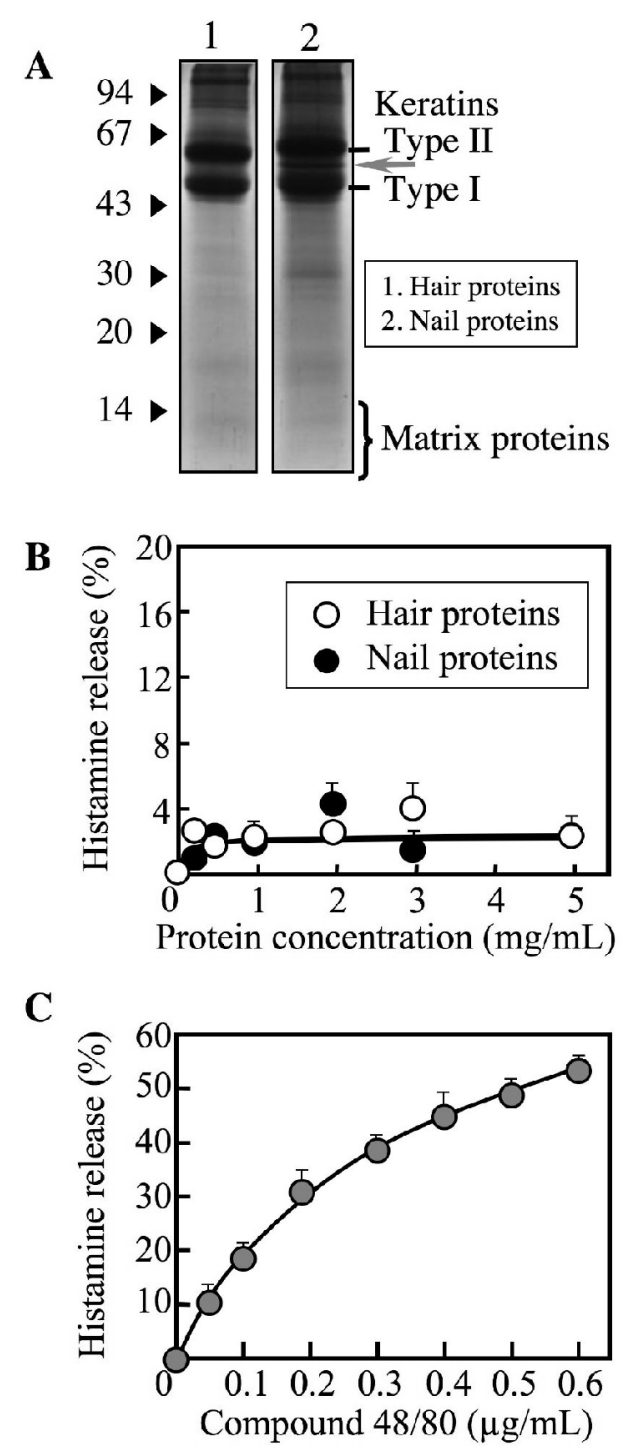

Figure 1. SDS-PAGE of human hair and nail proteins and histamine release from rat mast cells by compound $48 / 80$, hair proteins, and nail proteins.

Proteins were prepared from washed human hair and nail by the Shindai method and subjected to $13.5 \%$ SDS-PAGE (A). Rat peritoneal mast cells were preincubated for $5 \mathrm{~min}$ at $37^{\circ} \mathrm{C}$ in the presence of various concentrations of compound 48/80 (B) and the hair ( $\circ$ ) and nail proteins $(\bullet)$ ), as indicated (C). The cells were challenged with $0.9 \mathrm{mM} \mathrm{CaCl}_{2}$ for $10 \mathrm{~min}$ at $37^{\circ} \mathrm{C}$ and the amount of released histamine was measured. Values are expressed as means \pm S.D. for 3-4 experiments. 
No stimulation

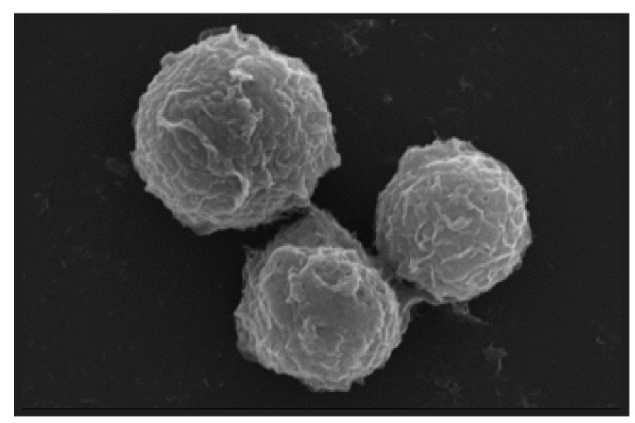

Nail proteins

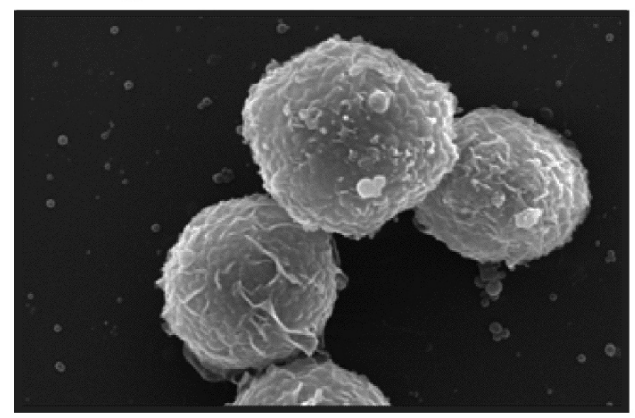

Hair proteins

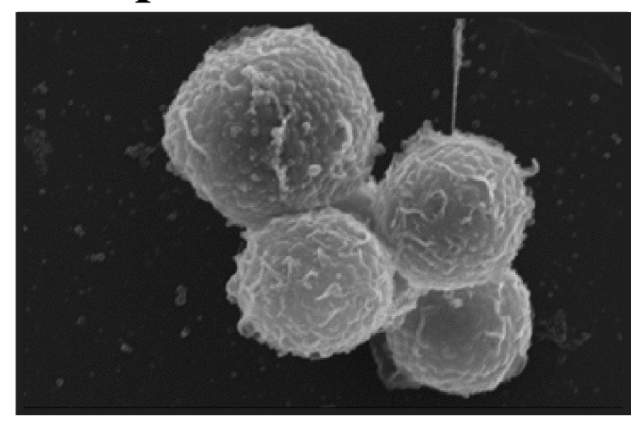

Compound 48/80

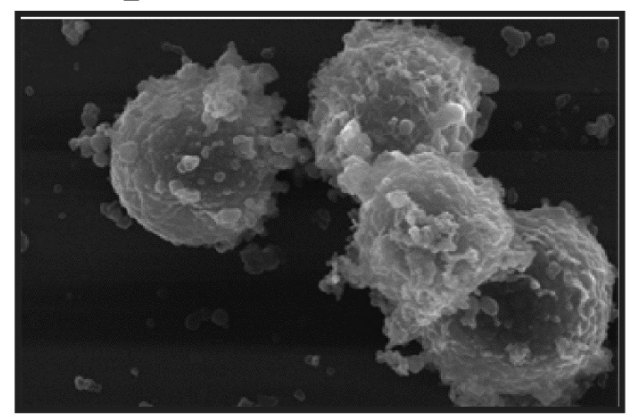

$10 \mu \mathrm{m}$

Figure 2. Morphological observations of mast cells incubated with compound 48/80, hair proteins, and nail proteins. The mast cells were exposed to compound 48/80, the hair proteins, and the nail proteins as shown in Figure 1 and observed by SEM. The concentrations of compound 48/80, the hair proteins, and the nail proteins were $0.3 \mu \mathrm{g} \cdot \mathrm{mL}^{-1}, 3 \mathrm{mg} \cdot \mathrm{mL}^{-1}$, and $3 \mathrm{mg} \cdot \mathrm{mL}^{-1}$, respectively. Bars, $10 \mu \mathrm{m}$. 
Figure 3. Morphological observation of hair protein films. The hair protein films were prepared by the Post-cast method (A, $100 \mathrm{mM}$ acetate buffer, $\mathrm{pH} 4$ and $\mathrm{B}, 100 \mathrm{mM}$ acetate buffer, $\mathrm{pH}$ 5) and soft Post-cast method (C, $40 \mathrm{mM}$ $\mathrm{MgCl}_{2}$ ) and observed by SEM. Bars, $10 \mu \mathrm{m}$. 

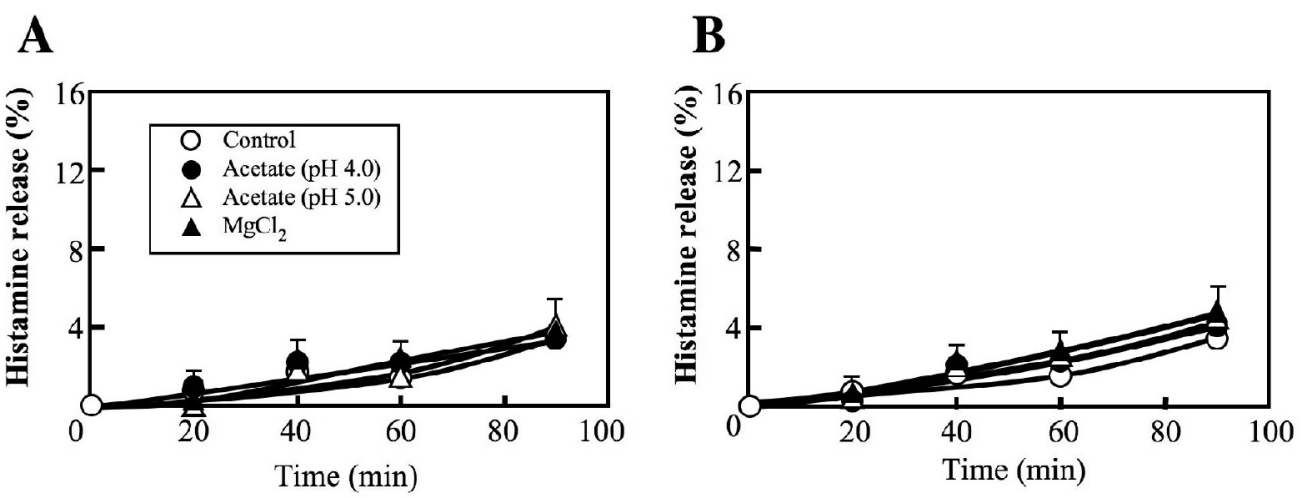

C

\section{Acetate buffer (pH 4.0)}

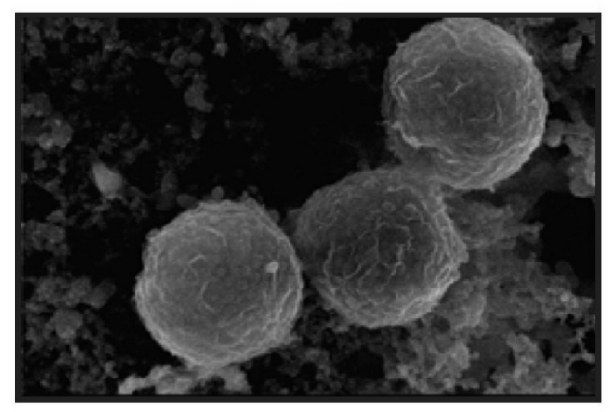

Acetate buffer (pH 5.0)

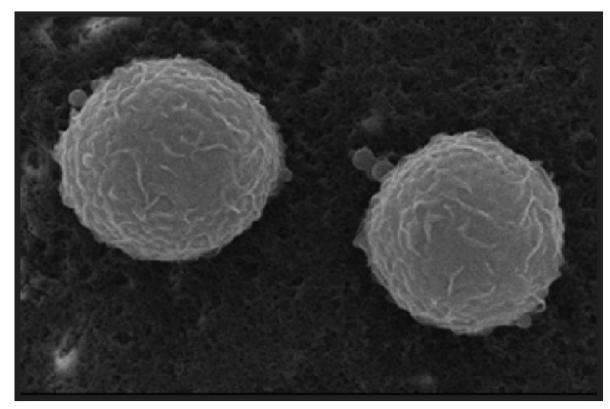

\section{$\mathrm{MgCl}_{2}$}

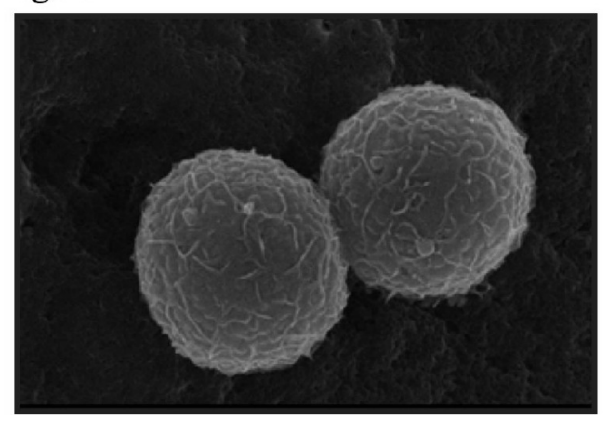

Figure 4. Histamine release from rat mast cells exposed to hair and nail protein films and morphological observations. The mast cells were incubated for $5 \mathrm{~min}$ at $37^{\circ} \mathrm{C}$ on the hair (A) and nail (B) protein films as shown in Figure

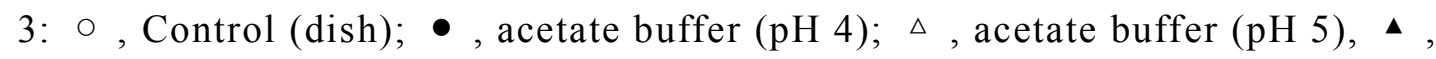
$40 \mathrm{mM} \mathrm{MgCl}_{2}$. The cells were challenged with $0.9 \mathrm{mM} \mathrm{CaCl}_{2}$ for $10 \mathrm{~min}$ at 37 ${ }^{\circ} \mathrm{C}$, and the amount of released histamine was measured. Values are expressed as means \pm S.D. for 3-4 experiments. The mast cells after incubation with the protein films for 60 min were observed by SEM (C). 

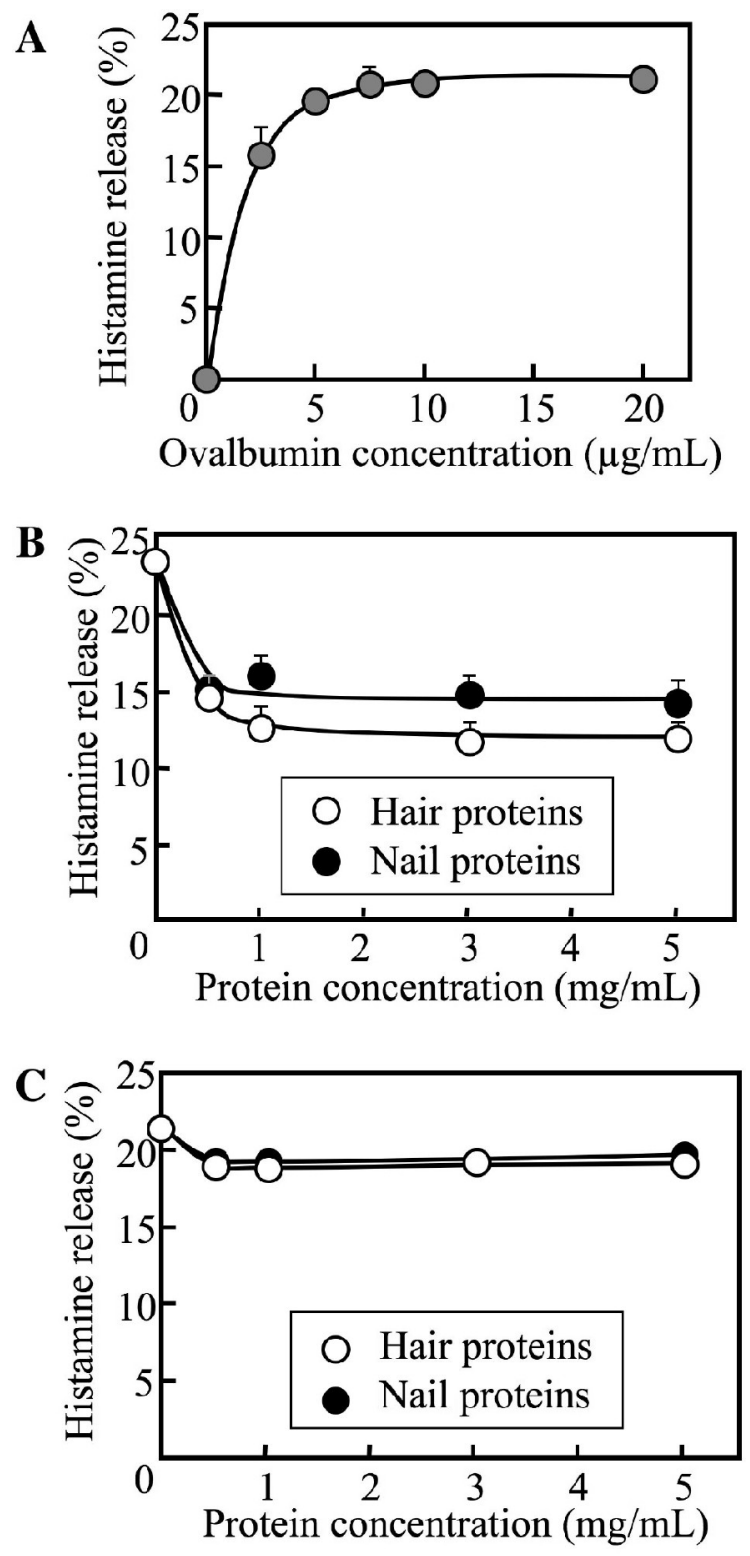

Figure 5. Effects of the hair and nail proteins on the IgE-dependent histamine release from mast cells. The mast cells were incubated with IgE serum for 60 min at $37{ }^{\circ} \mathrm{C}$ and then stimulated for $10 \mathrm{~min}$ at $37{ }^{\circ} \mathrm{C}$ with various concentrations of ovalbumin as indicated (A). The histamine release was measured when the obalbumin was added after preincubation of the mast cells with hair $(\circ)$ and nail proteins $(\bullet)(B)$ and when the hair and nail proteins were added after preincubation of the mast cells with IgE serum (C). Values are expressed as means \pm S.D. for 3-4 experiments. 
Figure 6. Effects of hair and nail protein films on IgE-dependent histamine release from mast cells. The mast cells on the control dish (a), hair protein films (b-d), and nail protein films (e-g) were incubated with IgE serum for 60 min at $37{ }^{\circ} \mathrm{C}$ and stimulated for $10 \mathrm{~min}$ at $37{ }^{\circ} \mathrm{C}$ with $10 \mu \mathrm{g} \cdot \mathrm{mL}^{-1}$ ovalbumin. The dishes were coated with protein films; Post-cast method (b and e, $100 \mathrm{mM}$ acetate buffer, pH 4), Post-cast method (c and f, $100 \mathrm{mM}$ acetate buffer, $\mathrm{pH} 5$ ), and soft Post-cast method ( $\mathrm{d}$ and $\mathrm{g}, 40 \mathrm{mM} \mathrm{MgCl}{ }_{2}$ ). Values are expressed as means \pm S.D. for 3-4 experiments. 